Corresponding Author: Hagir Abd Rahman Mahmoud Ali;

email: hagir3@hotmail.com

Received 26 July 2021

Accepted 09 July 2021

Published 30 September 2021

Production and Hosting by Knowledge E

(c). This article is distributed under the terms of the

Creative Commons

Attribution License, which permits unrestricted use and redistribution provided that the original author and source are credited.

Editor-in-Chief:

Prof. Mohammad A. M. Ibnouf

\section{Prevalence and Severity of Dental Fluorosis among Primary School Children Aged 12-14 Years in Abosied and Alfetehab Localities, Omdurman, Sudan}

Hagir Abd Rahman Mahmoud Ali ${ }^{1}$ and Moneer Mohammed Alhassn Algdal²

${ }^{1}$ Faculty of Dental and Oral Medicine, Kararay University, Omdurman, Sudan

${ }^{2}$ Omdurman Military Hospital, Omdurman, Sudan

ORCID:

Hagir Abd Rahman Mahmoud Ali: https://orcid.org/0000-0002-4969-6614

\section{Abstract}

Background: Dental fluorosis is a disease of dental hard tissues resulting from excess fluoride intake during the developmental stages of teeth causing hypomineralization of the enamel. This study aimed to assess the prevalence of dental fluorosis among school children in Omdurman locality.

Methods: Students in the sixth grade of school were examined to determine the prevalence of dental fluorosis using Dean's index.

Results: The prevalence of dental fluorosis was $68.3 \%$. The majority of students were diagnosed with very mild (23.2\%) and mild (26.5\%) forms. There was no difference in the grade of fluorosis between children who were born outside and in Omdurman.

Conclusion: Prevalence of dental fluoride was found to be very high among school children with no difference between males and females.

Keywords: fluorosis, Sudan, school children

\section{Introduction}

Fluoride is a natural element found in drinking water. Consumption of fluoride is essential because of its impact on dental health. Fluoride ions replace the hydroxyl in the hydroxyapatite crystals resulting in fluorapatite crystals which decreases the solubility of tooth structures [1].

The optimal fluoride concentration in drinking water which promotes dental health is 0.5-1.5 mg/L [2, 3]. However, there are areas with low fluoride levels, so these individual communities added fluoride to their drinking water in a procedure called fluoridation [4]. This was done to increase the concentration of fluoride in drinking water to prevent dental caries and protect tooth development in young children.

On the other hand, fluoride content of $1.5-4 \mathrm{mg} / \mathrm{L}$ in drinking water leads to dental S OPEN ACCESS 
$[2,3]$. Dental fluorosis is a developmental disease caused by excessive intake of fluoride during the periods of tooth development leading to hypomineralization of the enamel $[5,6]$.

In most areas of Sudan, water from wells is used for domestic and livestock consumption, and as high concentration of fluoride in water are generally found in groundwater, this study therefore aims to assess the prevalence of dental fluorosis.

\section{Materials and Methods}

This school-based, cross-sectional study was conducted during the school health program held by the Faculty of Dentistry, Karary University. The program targeted 13 public schools in Abosied and Alfetehab localities in Omdurman city. The target group was students studying in the sixth grade of school excluding children with orthodontic brackets, crowns, or fractured anterior teeth. The clinical examination was carried out in the school premises by the researcher. Children were seated on ordinary chair under natural day light, the examinations were carried out without prior cleaning or drying of the teeth and the instruments used were sterilized mouth mirror, probe, and dental tweezer. The severity of the fluorosis was assessed using Dean's index which is a six-point ordinal scale [7] (Table 1).

TABLE 1: Dean's Index for dental fluorosis [7].

$\begin{array}{lll}\text { Classification } & \text { Criteria } \\ \text { Normal (0) } & \begin{array}{l}\text { The enamel represents the usual translucency with smooth and glossy surface } \\ \text { with a pale, creamy color. }\end{array} \\ \begin{array}{ll}\text { Questionable } \\ (0.5)\end{array} & \begin{array}{l}\text { A definitive diagnosis of the mildest form of fluorosis is not warranted and a } \\ \text { classification of "normal" not justified. }\end{array} \\ \text { Very mild (1) } & \begin{array}{l}\text { Small opaque, white areas that are scattered or streaked over the tooth, but not } \\ \text { involving as much as approximately } 25 \% \text { of the tooth surface. }\end{array} \\ \text { Mild (2) } & \begin{array}{l}\text { The white opaque areas in the enamel of the teeth are more extensive, but do not } \\ \text { involve as much as } 50 \% \text { of the tooth surface. }\end{array} \\ \text { Moderate (3) } & \begin{array}{l}\text { All enamel surfaces of the teeth are affected, and surfaces subject to attrition show } \\ \text { wear. Brown stain is frequently a disfiguring feature. }\end{array} \\ \text { Severe (4) } & \begin{array}{l}\text { All enamel surfaces are affected and hypoplasia is marked that the general form of } \\ \text { the tooth may be affected. Discrete or confluent pits are extensive and Brown } \\ \text { stains are widespread. }\end{array}\end{array}$




\section{Results}

The study was performed on 578 students of which 411 (71.1\%) were girls and 167 (28.9\%) were boys. The mean age of subjects surveyed was $11.6 \pm 1$ years ranging from 10 to 16 years. 401 (69.4\%) children were born in Omdurman locality.

Dental fluorosis was detected in approximately $68.3 \%$ of the students examined $(n=$ $395)$, and the community fluorosis index was $1.10 \pm 1.02$. The majority of students were diagnosed as having very mild (23.2\%) and mild (26.5\%) forms of fluorosis (Figure 1). It was observed that students having severe fluorosis status were $80 \%$ boys and $20 \%$ girls. There was no difference in the grade of dental fluorosis between children who were born outside and in Omdurman (Table 2).

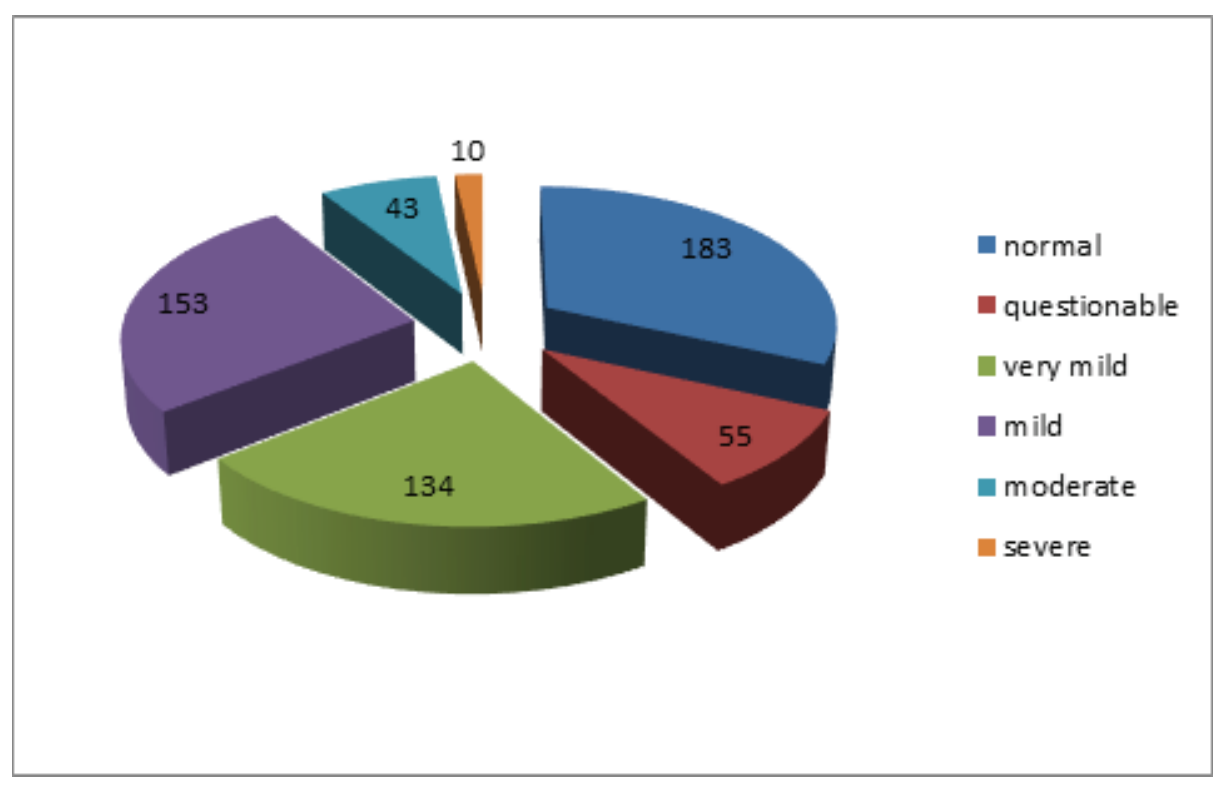

Figure 1: Prevalence of dental fluorosis among school students.

TABLE 2: Comparison of the Dean's index with respect to the students' gender and place of birth.

\begin{tabular}{|c|c|c|c|c|c|c|c|c|}
\hline & & \multicolumn{6}{|c|}{ Fluorosis level } & \multirow{2}{*}{$\begin{array}{l}P \text { - } \\
\text { value }\end{array}$} \\
\hline & & Normal & Questionable & Very mild & Mild & Moderate & Severe & \\
\hline \multirow[t]{2}{*}{ Gender } & Male & 51 (27.9\%) & $13(23.6 \%)$ & 36 (26.9\%) & 45 (29.4\%) & $14(32.6 \%)$ & 8 (80.0\%) & 0.015 \\
\hline & Female & 132 (72.1\%) & 42 (76.4\%) & 98 (73.1\%) & 108 (70.6\%) & 29 (67.4\%) & 2 (20.0\%) & \\
\hline \multirow[t]{2}{*}{ Birthplace } & Omdurman & 130 (71.0\%) & 40 (72.7\%) & 95 (70.9\%) & 102 (66.7\%) & 28 (65.1\%) & $6(60.0 \%)$ & 0.851 \\
\hline & $\begin{array}{l}\text { Outside } \\
\text { Omdurman }\end{array}$ & 53 (29.0\%) & 15 (27.3\%) & 39 (29.1\%) & 51 (33.3\%) & 15 (34.9\%) & 4 (40.0\%) & \\
\hline
\end{tabular}

${ }^{*}$ Chi-square test. 
TABLE 3: Summary of previous studies on the prevalence of dental fluorosis

\begin{tabular}{|c|c|c|c|c|c|}
\hline Country & Fluoride level & Study population & Number & $\begin{array}{l}\text { Prevalence of } \\
\text { fluorosis }\end{array}$ & Gender \\
\hline Butana Sudan [10] & $1.1-4.0 \mathrm{mg} / \mathrm{L}$ & $\begin{array}{l}\text { Students 7-14 } \\
\text { years }\end{array}$ & 134 & $60.6 \%$ & $\begin{array}{l}\text { Not } \\
\text { mentioned }\end{array}$ \\
\hline Treitel Biga Sudan [11] & $0.25 \mathrm{ppm}$ & $\begin{array}{l}\text { Students 6-12 } \\
\text { years }\end{array}$ & 55 & $91 \%$ & Males \\
\hline Abu Groon Sudan [11] & $2.56 \mathrm{ppm}$ & $\begin{array}{l}\text { Students 6-12 } \\
\text { years }\end{array}$ & 58 & $100 \%$ & Equal \\
\hline $\begin{array}{l}\text { Tiraat El-Bijah Sudan } \\
\text { [12] }\end{array}$ & $\begin{array}{l}0.24-1.31 \\
\mathrm{mg} / \mathrm{L}\end{array}$ & All ages & 400 & $42.5 \%$ & Equal \\
\hline $\begin{array}{l}\text { UmDuwanban Sudan } \\
\text { [12] }\end{array}$ & $\begin{array}{l}1.29-1.43 \\
\mathrm{mg} / \mathrm{L}\end{array}$ & All ages & 400 & $70 \%$ & Equal \\
\hline India [13] & $\leq 1.5 \mathrm{mg} / \mathrm{L}$ & $\begin{array}{l}\text { Students } 12 \& 15 \\
\text { years }\end{array}$ & 1875 & $29.8 \%$ & Equal \\
\hline India [14] & $\leq 1.5 \mathrm{mg} / \mathrm{L}$ & All ages & 6093 & $39.2 \%$ & Males \\
\hline India [15] & $2.42 \mathrm{mg} / \mathrm{dL}$ & $\begin{array}{l}\text { Students 6-12 } \\
\text { years }\end{array}$ & 1008 & $69.84 \%$ & $\begin{array}{l}\text { Not } \\
\text { mentioned }\end{array}$ \\
\hline India [16] & $\begin{array}{l}\text { Not } \\
\text { mentioned }\end{array}$ & $\begin{array}{l}\text { Students } 12-15 \\
\text { years }\end{array}$ & 840 & $82.04 \%$ & Equal \\
\hline India [17] & $0.53-5 \mathrm{ppm}$ & $\begin{array}{l}\text { students 6-14 } \\
\text { year }\end{array}$ & 178 & $78 \%$ & Females \\
\hline India [18] & $<0.2-6.5 \mathrm{ppm}$ & $\begin{array}{l}\text { Students 5-12 } \\
\text { years }\end{array}$ & 1800 & $4.1 \%$ & Females \\
\hline India [19] & $<0.1 \mathrm{ppm}$ & $\begin{array}{l}\text { Students 5-12 } \\
\text { years }\end{array}$ & 525 & $31.4 \%$ & Equal \\
\hline Ghana [20] & 1.50 ppm & $\begin{array}{l}\text { Children 7-18 } \\
\text { years }\end{array}$ & 200 & $63 \%$ & Equal \\
\hline Saudi Arabia [21] & $\begin{array}{l}\text { Not } \\
\text { mentioned }\end{array}$ & All ages & 253 & $73.5 \%$ & Equal \\
\hline Mexico [22] & $1.41 \mathrm{mg} / \mathrm{L}$ & $\begin{array}{l}\text { Students 12-15 } \\
\text { years }\end{array}$ & 101 & $85 \%$ & Equal \\
\hline Mexico [23] & 1.95 ppm & $\begin{array}{l}\text { Students } 12 \& 15 \\
\text { years }\end{array}$ & 1024 & $83.8 \%$ & Equal \\
\hline Mexico [24] & $\begin{array}{l}\text { Not } \\
\text { mentioned }\end{array}$ & $\begin{array}{l}\text { Students 10-12 } \\
\text { years }\end{array}$ & 239 & $59 \%$ & Equal \\
\hline Brazil [25] & $\begin{array}{l}\text { Not } \\
\text { mentioned }\end{array}$ & $\begin{array}{l}\text { students } 12 \& \\
15-19 \text { years }\end{array}$ & 535 & $25 \%$ & Females \\
\hline Brazil [26] & $0.9 \mathrm{mg} / \mathrm{L}$ & $\begin{array}{l}\text { Students } 7 \& 15 \\
\text { years }\end{array}$ & 52 & $33 \%$ & $\begin{array}{l}\text { Not } \\
\text { mentioned }\end{array}$ \\
\hline
\end{tabular}

\section{Discussion}

This study was conducted in Aboseid and Alftihab localities which covers an area of $49 \mathrm{~km}^{2}$. There were a total of 50 governmental primary schools. The water sources in this area are wells and the Nile. The average fluoride concentration in the water wells was $0.675 \mathrm{ppm}$, while the fluoride concentration in the Nile was $0.35 \mathrm{ppm}$. This fluoride level was below the level recommended by the WHO [8]. 


\subsection{Fluorosis}

Several studies have been conducted across the world regarding the degree of dental fluorosis compared to the fluoride levels in drinking water, these studies are summarized in Table 3.

In the present study, nearly two-thirds (68.3\%) of children experienced dental fluorosis, this showed a high prevalence despite the fluoride level being $\bowtie 1 \mathrm{mg}-\mathrm{F} / \mathrm{L}$. Other studies from Sudan also showed high fluorosis incidence, however, they were conducted in areas with high fluoride level like Butana $[9,10]$. Many areas in Al-Butana region had a high concentration of fluoride; a study aimed at measuring fluoride level in different wells in Al-Butana region showed that in the northern part, the levels ranged from 0.5 to $1.5 \mathrm{mg} / \mathrm{L}$, while in the southern part, the level was $<0.5 \mathrm{mg} / \mathrm{L}$, and the levels of 1.5 $\mathrm{mg} / \mathrm{L}$ were limited and scattered throughout the area [9].

A study in Butana showed that the prevalence of fluorosis was about $60.6 \%$, with a fluoride level in drinking water ranging from 1.1 to $4.0 \mathrm{mg}-\mathrm{F} / \mathrm{L}$ [10]. Ibrahim et al. studied the fluoride levels of drinking water and assessed the prevalence of dental fluorosis among children in Treitel Biga and Abu Groon areas. The level of fluoride in Treitel Biga was $0.25 \mathrm{ppm}$, while in Abu Groon it was $2.56 \mathrm{ppm}$. The study reported a 91\% and $100 \%$ prevalence of dental fluorosis in Treitel Biga and Abu Groon areas, respectively [11]. Another study from Tiraat El-Bijah and UmDuwanban reported a prevalence of about $42.5 \%$ and $70 \%$ dental fluorosis with a fluoride level of $0.45 \mathrm{mg} / \mathrm{L}$ and $1.36 \mathrm{mg} / \mathrm{L}$, respectively [12].

The high dental fluorosis in this study could be explained by the fact that in hot areas, the amount of consumed water is increased, thus increasing the amount of fluoride ingested leading to dental fluorosis. This was supported by another study from Sudan which calculated the higher allowed fluoride level in drinkable water as 0.35 ppm [27]

Similar results from an Indian studies which were conducted in low fluoride areas ( $\leq 1.5 \mathrm{mg} / \mathrm{L}$ ) showed a dental fluorosis prevalence of $29.8 \%$ [13] and 39.2\% [14]. Studies from different parts of the world showed diverse fluorosis prevalence, high prevalence was reported by many studies; Indian studies reported a prevalence of $69.8-82.04 \%$ [13, 15-17]. A study was carried in Bongo community of Ghana reported a 63\% prevalence [20]. Moreover, a 73.5\% prevalence was recorded from Hail, Saudi Arabia [21], two studies from Mexico reported a prevalence of $85 \%$ [22] and 83.8\%, respectively [23], and a study of students living in Mexico City reported a prevalence 58.6\% [24]. However, many studies showed lower rates for fluorosis; a Brazilian study reported a prevalence 
of $25 \%$ [25] and two studies from India showed dental fluorosis to be $4.1 \%$ [18] and $31.4 \%$ [19].

Of note, females and males have the similar likelihood of developing dental fluorosis [22]. Similar results were found in this study with no significant difference between genders, this is consistent with other studies conducted in Sudan [12], and among Bongo community of Ghana [20], Saudi Arabia [21], Mexico City [24], and India [13, $16,19]$. However, some studies have concluded that gender was associated with dental fluorosis, with some studies showing fluorosis to be more prevalent in females [17, 18, 25]. One study of children from Omdurman reported a $64 \%$ and $50 \%$ prevalence of dental fluorosis among boys and girls, respectively [28], another study showed that in Treitel Biga, the prevalence and severity of fluorosis was higher among boys than girls [11]; in addition, another study from India reported that the overall percentage of dental fluorosis was more in males than in females [14].

The predominant categories of fluorosis were very mild and mild (49.7\%), and only 9.1\% were in the moderate and severe types, respectively; those few children with increased severity may have had an overexposure to fluoride from other sources like toothpastes. These results are consistent with the results of a Sudanese study that found that the predominant categories in their study were very mild and mild [12] and a study from Mexico City that reported very mild and mild fluorosis in 51.9\% of their students and moderate or severe levels in only 6.69\% [24]. Similarly, an Indian study didn't report severe fluorosis and the prevalence of moderate fluorosis was $0.2 \%$ [18] However, another Indian study showed a more severe results with $29.8 \%$ students showing moderate and $6.7 \%$ severe fluorosis [17].

\section{Conclusion}

Prevalence of dental fluoride was found to be very high among school children with no difference between males and females. Although the majority of dental fluorosis were in the categories of very mild and mild, concerns regarding its growing prevalence underscores the need for careful observation.

\section{Acknowledgements}

The authors would like to thank the faculty of dental and oral medicine, karary University for facilitation of the school health program. 


\section{Ethical Considerations}

Ethical approval was obtained from the ethical committee at the Faculty of Oral and Dental Medicine. Agreement to examine the children was abstained from the school's principals as this examination was part of a school health program carried out by the Ministry of Health.

\section{Competing Interests}

There is no competing interest.

\section{Availability of Data and Material}

All data used in this study are available upon reasonable request with the corresponding author.

\section{Funding}

None received.

\section{References}

[1] Ten Cate, J. and Featherstone, J. (1991). Mechanistic aspects of the interactions between fluoride and dental enamel. Critical Reviews in Oral Biology \& Medicine, vol. 2, no. 3, pp. 283-296.

[2] WHO. (1994). Drinking water quality control in small community supplies (vol. II). Geneva: WHO.

[3] Bailey, J., Chilton, J., Dahi, E., et al. (2006). Fluoride in drinking-water. Geneva: World Health Organization..

[4] WHO. (2017). Guidelines for drinking-water quality: fourth edition incorporating the first addendum. Geneva: WHO.

[5] DenBesten, P. and Li, W. (2011). Chronic fluoride toxicity: dental fluorosis. Fluoride and the Oral Environment, vol. 22, pp. 81-96.

[6] Burt, B. A. and Eklund, S. A. (2005). Dentistry, dental practice, and the community. Elsevier Health Sciences. 
[7] Dean, H. T. (1934). Classification of mottled enamel diagnosis. The Journal of the American Dental Association, vol. 21, no. 8, pp. 1421-1426.

[8] Fawell, J. K. and Bailey, K. (2006). Fluoride in drinking-water. Geneva: WHO.

[9] Abdel-Magid, H. M., Abdellah, A. M., and Yahia, N. A. (2011). Well drinking water fluoride content and dental fluorosis in Al-Butana region of central Sudan. Asian Journal of Water, Environment and Pollution, vol. 8, no. 4, pp. 37-46.

[10] Smith, D., Harris, H., and Kirk, R. (1953). Fluorosis in the Butana, Sudan. Journal of Tropical Medicine and Hygiene, vol. 56, pp. 57-58.

[11] Ibrahim, Y., Affan, A., and Bjorvatn, K. (1995). Prevalence of dental fluorosis in Sudanese children from two villages with 0.25 and 2.56 ppm fluoride in the drinking water. International Journal of Paediatric Dentistry, vol. 5, no. 4, pp. 223-229.

[12] Ramadan, A. and Ghandourb, I. (2016). Dental fluorosis in two communities in Khartoum state, Sudan, with potable water fluoride levels of 1.36 and $0.45 \mathrm{mg} / \mathrm{L}$. Fluoride, vol. 49, no. 4, pp. 509-520.

[13] Sukhabogi, J. R., Parthasarathi, P., Anjum, S., et al. (2015). Dental fluorosis and dental caries prevalence among 12 and 15 year old school children in Nalgonda district, Andhra Pradesh, India. Annals of Medical and Health Sciences Research, vol. 4, no. 3, pp. 245-252.

[14] Kotecha, P. V., Patel, S. V., Bhalani, K. D., et al. (2012). Prevalence of dental fluorosis \& dental caries in association with high levels of drinking water fluoride content in a district of Gujarat, India. Indian Journal of Medical Research, vol. 135, no. 6, pp. 873-877.

[15] Sarvaiya, B., Bhayya, D., Arora, R., et al. (2012). Prevalence of dental fluorosis in relation with different fluoride levels in drinking water among school going children in Sarada tehsil of Udaipur district, Rajasthan. Journal of Indian Society of Pedodontics and Preventive Dentistry, vol. 30, no. 4, p. 317.

[16] Naidu, G. M., Rahamthullah, S. U., Kopuri, R. K. C., et al. (2013). Prevalence and self perception of Dental Fluorosis among 15 year old school children in Prakasham district of south India. Journal of International Oral Health, vol. 5, no. 6, p. 67.

[17] Varsha, D. and Ragini, M. (2013). Prevalence and severity of dental fluorosis among school students in Dongargaon of Chandrapur district, Maharashtra, India. Journal of Environmental Research and Development, vol. 8, no. 2, p. 309.

[18] Chauhan, D., Chauhan, T., Sachdev, V., et al. (2012). A study of prevalence and severity of dental fluorosis among school children in a Northern hilly state of India. SRM Journal of Research in Dental Sciences, vol. 3, no. 3, p. 170. 
[19] Saravanan, S., Kalyani, C., Vijayarani, M., et al. (2008). Prevalence of dental fluorosis among primary school children in rural areas of Chidambaram Taluk, Cuddalore District, Tamil Nadu, India. Indian Journal of Community Medicine, vol. 33, no. 3, p. 146.

[20] Firempong, C., Nsiah, K., Awunyo-Vitor, D., et al. (2013). Soluble fluoride levels in drinking water-a major risk factor of dental fluorosis among children in Bongo community of Ghana. Ghana Medical Journal, vol. 47, no. 1, pp. 16-23.

[21] Alhobeira, H. A., Siddiqui, A. A., and Mian, R. I. (2015). Prevalence and severity of dental fluorosis in Hail, Saudi Arabia. Journal of International Oral Health, vol. 7, no. 12.

[22] Vazquez-Alvarado, P., Prieto-García, F., Coronel-Olivares, C., et al. (2010). Fluorides and dental fluorosis in students from Tula de Allende Hidalgo, Mexico. Journal of Toxicology and Environmental Health Sciences, vol. 2, no. 3, pp. 24-31.

[23] Pontigo-Loyola, A. P., Islas-Márquez, A., Loyola-Rodríguez, J. P., et al. (2008). Dental fluorosis in 12-and 15-year-olds at high altitudes in above-optimal fluoridated communities in Mexico. Journal of Public Health Dentistry, vol. 68, no. 3, pp. 163-166.

[24] Molina-Frechero, N., Gaona, E., Angulo, M., et al. (2015). Fluoride exposure effects and dental fluorosis in children in Mexico City. Medical Science Monitor, vol. 21, pp. 3664-3670.

[25] Rigo, L., Caldas Junior A. dF., Souza, E. H. Ad. (2010). Factors associated with dental fluorosis. Revista Odonto Ciência, vol. 25, no. 1, pp. 8-14.

[26] Ramires, I., Olympio, K. P. K., Maria, A. G., et al. (2006). Fluoridation of the public water supply and prevalence of dental fluorosis in a peripheral district of the municipality of Bauru, SP. Journal of Applied Oral Science, vol. 14, no. 2, pp. 136-141.

[27] Ramadan, A. and Hilmi, Y. (2014). The influence of climate on the determination of the upper permissible fluoride level in potable water in Sudan. Fluoride, vol. 47, pp. 123-133.

[28] Aziz Ghandour, I. A., Ibrahim, F. A., and Shehata, A. H. (1988). The prevalence of dental caries, fluorosis, and dental attitudes among primary schoolchildren in OmdurmanSudan. Odonto-stomatologie Tropicale, vol. 11, no. 3, pp. 103-106. 